\title{
SIMULATION OPTIMIZATION APPROACH TO PERIODIC REVIEW INVENTORY CONTROL SYSTEM WITH BACKORDERS
}

\author{
Ayşe Tuğba DOSDOĞRU ${ }^{1}$ \\ Asli BORU İPEK ${ }^{2}$ \\ Mustafa GÖÇKEN ${ }^{3}$ \\ Tolunay GÖÇKEN ${ }^{4}$
}

\begin{abstract}
In today's competitive world, companies should minimize cost while providing high quality goods. Companies generally try to reduce the level of inventory to minimize the cost and therefore they usually observe shortage in practice. At this point, using of the right inventory control policy is the most effective and efficient way to reduce shortage. In inventory control policies, the basic question is to specify the size and the timing of a replenishment order in supply chain members. Over the years, many advanced methods have been applied to answer these questions. Due to the difficulty of dealing with the uncertainties in supply chain environment, simulation optimization (SO) is used in this study to get the application of goals in supply chain. Although SO requires a great deal of understanding related with inventory control system, the use of SO brings such complex system within the grasp of managers. In this paper, SO is used to analyze the supplier selection and inventory control system simultaneously. The system results clearly reveals that the best values of inventory control variables and the most suitable suppliers can be determined by SO in a two echelon supply chain model with backorder.
\end{abstract}

Keywords: Simulation Optimization, Inventory Control System, Supplier Selection

\section{ERTELENMIŞ SIPARISS DURUMUNU ELE ALAN PERIYYODIK STOK KONTROL SISTEMİ IÇCiN SIMÜLASYON OPTIMIZAASYONU YAKLAŞIMI}

\section{ÖZ}

Günümüzün rekabetçi iş dünyasında, şirketler yüksek kaliteli ürünler sunarken maliyetleri en aza indirgemelidir. Şirketler genellikle maliyeti en aza indirmek için stok seviyesini azaltmaya çalışmaktadır ve bu nedenle genellikle uygulamada eksiklikler gözlemlenmektedir. Bu noktada, doğru stok kontrol politikasının kullanılması, stok eksikliğinin azaltılmasında en etkili ve verimli yoludur. Stok kontrol politikalarında temel soru, tedarik zinciri üyelerinde siparișin boyutunun ve zamanlamasının belirlenmesidir. Yıllar boyunca, bu soruları yanıtlamak için birçok gelişmiş yöntem uygulanmıştır. Tedarik zincirlerinde bulunan belirsizlikler ile başa çıkmanın zor olması nedeniyle, tedarik zincirlerinde hedeflere ulaşmak için çalışmamızda simülasyon optimizasyonu (SO) kullanılmıştır. SO, stok kontrol sistemi ile ilgili büyük bilgi

${ }^{1}$ Dr. Öğr. Üyesi, Adana Alparslan Türkeş Science and Technology University, Faculty of Engineering, Department of Industrial Engineering, adosdogru@ @atu.edu.tr, ORCID: 0000-0002-1548-5237 ${ }^{2}$ Dr. Araștırma Görevlisi, Adana Alparslan Türkes Science and Technology University, Faculty of Engineering, Department of Industrial Engineering aboru@ atu.edu.tr, ORCID: 0000-0001-6403-5307

${ }^{3}$ Doçent, Adana Alparslan Türkeş Science and Technology University, Faculty of Engineering, Department of Industrial Engineering mgocken@ atu.edu.tr, ORCID: 0000-0002-1256-2305

${ }^{4}$ Doçent, Adana Alparslan Türkeş Science and Technology University, Faculty of Engineering, Department of Industrial Engineering tgocken@atu.edu.tr, ORCID: 0000-0002-5953-175X

Received/Geliş: 05/12/2018 Accepted/Kabul: 18/03/2020, Research Article/Araştırma Makalesi

Cite as/Alıntı: Dosdoğru, A., Boru, A., Göçken, M., Göçken, T. (2020), "Simulation Optimization Approach To Periodic Review Inventory Control System With Backorders", Çukurova Üniversitesi Sosyal Bilimler Enstitüsü Dergisi, cilt 29, sayı 1, s.200-212. 
birikimi gerektirse de, SO kullanımı yöneticilerin bu karmaşık sistemi anlamasında kolaylık sağlamaktadır. Bu çalışmada, tedarikçi seçimini ve stok kontrol sistemini aynı anda analiz etmek için SO kullanılmaktadır. Çalışmanın sonuçları, ertelenmiş sipariş durumunu ele alan iki aşamalı tedarik zinciri modelinde, stok kontrol değişkenlerinin optimal değerinin ve en uygun tedarikçilerin SO tarafindan belirlenebileceğini açıkça ortaya koymaktadır.

Anahtar Sözcükler: Simülasyon Optimizasyonu, Stok Kontrol Sistemi, Tedarikçi Seçimi

\section{Introduction}

Free trade and globalization have led to increased competition among the companies in the world. Companies should carry out theirs operation efficiently to minimize cost and to improve the competitive advantage of the company (Sarker, Rochanaluk, \& Egbelu, 2014). At this point, supply chain operations are catching the attention of researchers due to numerous opportunities for cost savings. In supply chain, inventory is one of the essential resources needed for day-to-day operations. Many of the activities depend on the correct level of inventory being held. Planning should be undertaken to identify inventory level that will be needed for operations. Replenishment is also an important process to maintain inventory at optimum level. Depending on the nature of the supply chain operations, the planning and replenishment approach can be different (Mercado, 2008). However, companies often try to reduce the level of inventory to economize on inventory holding cost in today's competitive world. Hence, they usually observe shortage in practice. Customers generally respond differently to the shortage situation. Consumer reactions usually depend on the market environment and the type of commodity (Rad, Khoshalhan, \& Glock, 2014). In order to reduce the loss in customer goodwill, companies should plan shortage considering the market environment and commodity. For example, customer demand can be considered as lost sales if the product is out of stock. In other cases, customers can wait for the product to be restocked and this case is known as backorders. In recent studies, various papers have considered stockout as backorder. We determined that there exists the need for developing a complete solution procedure for defining the best inventory control parameters with backorders cases. Our aim is to propose the SO to maintain a balanced inventory so that customer service is maintained within its proper limits.

\section{Literature Review}

The optimization techniques have differed in the knowledge required to provide the best solution to the inventory problem. Furthermore, these techniques have immensely varied in complexity both mathematical and conceptual skills needed. In addition, various factors such as demand, cost components, constraints are taken into account to fully define an inventory system (Cárdenas-Barrón, 2011). It is virtually impossible to summarize the literature related with the inventory problems in this short section. In addition, different properties of inventory control systems such as lost sales, backorders, and outsourcing give different results in problems. In this section, only backorder based inventory models are summarized in a chronological order. Rogers and Tsubakitan (1991) presented a general non-linear program for a multi-level inventory structure with backorders. Kok (1993) analyzed the backorder behavior for a one-product single echelon model in which continuous review (s, Q) policy was used with arbitrary demand processes and lead time distributions. Zhang, Patuwo, and Chu (2003) used the backorders and emergency orders in hybrid inventory control system to manage 
stockout. In the study, Poisson demand and a constant lead time were used in continuous review (Q, r) system. Gurgur and Altiok (2008) utilized a dynamically changing priority structure for multi-product production/inventory system where unsatisfied customer demand was backlogged.

Jaggi and Arneja (2011) created a stochastic inventory model using the Chebyshev inequality procedure that was employed to determine the optimal values of the backorder discount, the lead time, and the ordered quantity. For different levels of service, Chebyshev inequality was compared with Minimax and Normal approaches. Yao, Dong, and Dresner (2010) showed that lower inventory at the supply chain members can be associated with a higher conversion rate of lost sales stockouts to backorders under vendor managed inventory. It was also found that lower inventory at the distributor was related to higher backorder conversion rate. Bensoussan et al. (2010) used the dynamic programming equations for single-product and periodic-review system where unsatisfied demand was fully backordered. Cárdenas-Barrón (2011) proposed a hybrid geometric-algebraic method to determine the optimal lot size and the backorders level. In the study, sequential optimization procedure was developed using two stages in which the basic concept of analytic geometric was employed to optimize the backorders level and the algebraic method was utilized to determine the optimal lot size. Similarly, Chung and Cárdenas-Barrón (2012) presented an analytic approach to the economic order quantity and economic production quantity inventory models. In the study, proposed approach was created for only one product and all backorders are satisfied considering two type backorders cost.

Jawahar, Gunasekaran, and Balaji (2012) presented simulated annealing based heuristic for a two-echelon inventory system in which the suppliers' supply capacity and customers' demands were deterministic. Mart, Duran, and Bakal (2013) considered a manufacturer with production capacity restrictions. The problem was modelled as a Markov decision process. In each period, the optimal production, reserve and backorder amounts were taken into account by manufacturer. Rad et al. (2014) studied an integrated inventory model that considers operations and pricing decisions. There was a single vendor and single buyer for a single product with imperfect quality. It was assumed that shortages were backordered and products were defect-free.

Sarker et al. (2014) presented the inventory model that simultaneously defines the optimal order quantity and backorder quantity. Chen, Huang, Hassin, and Zhang (2015) presented the optimal inventory policy considering two types of pricing mechanisms under shortages: uniform compensation and priority auction. When a stockout situation was occurred, the firm offered the same discount to all customers under uniform compensation. On the other hand, priority was granted considering customer's bid price under the auction compensation. Samouei, Kheirkhah, and Fattahi (2015) proposed an algorithm considering constraints of in pipeline, out pipeline and repairing modes with backorders and quantity discount. In the study, mathematical model was firstly constructed. Then, it was simplified by removing unnecessary arcs and nodes. Srivastav and Agrawal (2016) used a multi-objective particle swarm optimization to define the optimal values of cost, order service level and fill rate. Rabbani, Oliaei, Farrokhi-Asl, and Mobini (2017) created a method that defines the optimal inter-cell and intra-cell formation layout and the production planning simultaneously. In the study, the demand of each part type was known per period and 
the backorder was considered in the cell formation problem. Johansson and Olsson (2017) presented a spare parts inventory control under two different backorder structures including piecewise constant backorder costs and general non-linear backorder costs. It was assumed that backorders at the sites and at the central warehouse were satisfied according to the first come-first served rule (FCFS). Furthermore, proposed method was used with time window service constraints to compare backorder and service level structures. Santis, Aguiar, and Goliatt (2017) proposed the application of a supervised learning model for backorder prediction in inventory control.

In the light of previous studies, we determined that managing uncertain inventories is one of the most important topics in inventory control system. Hence, it has received attention from academics and managers. Uncertainties in these supply chain members should be controlled in order to keep inventory levels as low as possible with minimum cost and high service level. This paper provides SO to respond changes and uncertainties in the supply chain, effectively. Basically, this paper serves the following purposes:

- Demonstrate how SO can be used to optimize supply chain decision variables;

- Develop a comprehensive SO models considering backorder for a two stage supply chain problem;

- Optimize the inventory control parameters and select proper suppliers for supply chain member simultaneously;

- Provide a deep understanding how the system reacts under stochastic environment.

\section{Proposed Simulation Optimization \\ Problem definition}

We consider a two-echelon inventory system with suppliers and distribution center (DC)s. Suppliers provide single non-perishable product for DCs. The distribution of the customer orders at DCs has a Poisson distribution with a rate parameter of 50. If customer order quantity exceeds the current inventory level, possible order fulfillment takes place. Unmet customer order quantity is backordered and we assume that backorders are filled according to the FCFS rule (Figure 1). Note that the FCFS rule is indeed reasonable from a practical point of view (Johansson and Olsson, 2018).

In this paper, $(\mathrm{R}, \mathrm{s}, \mathrm{S})$ policy is considered as inventory control policy for each supply chain member. In this policy, the inventory level of each supply chain member is inspected at every $\mathrm{R}$ time units. Note that $\mathrm{R}$ is assumed to be 5 days. At the beginning of each review period, the inventory level of each supply chain member is fulfilled until the order up to level (S) whenever it decreases to a value smaller than or equal to the reorder level (s). We used Genetic Algorithm (GA) to determine an initial inventory, order-up-to level, and reorder point for each DC and each Supplier. 


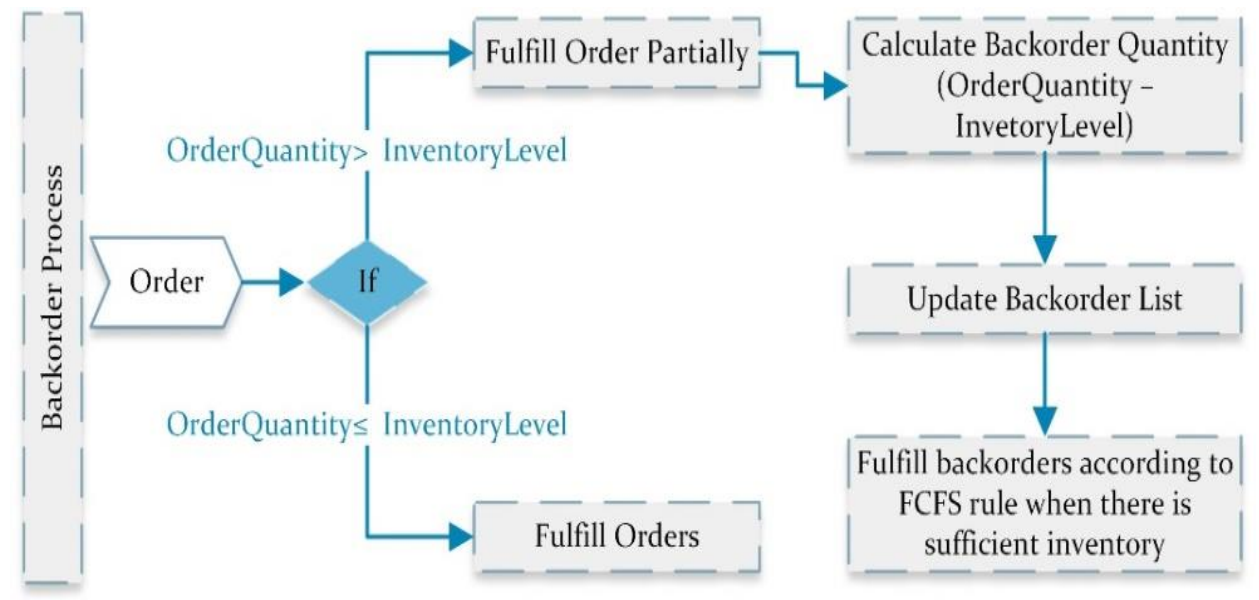

Figure 1. The proposed system of backorder process

\section{Simulation Optimization}

Due to the stochastic, nonlinear, and time-dependent nature, proposed inventory control system is quite complicated. To signify the dynamic behavior, all variables that evolve with time should be taken into account. At this point, SO can be used to allow a more detailed representation of complex supply chains. SO is generally preferred when analytic methods cannot give the solution in acceptable times. SO includes optimization methods and simulation analysis. The procedure of SO is sequential in nature. Basically, optimization method is used to optimize the configuration parameters within the simulation. The optimization method defines the new configurations with each iteration. In optimization method, the performance values are provided by the results of the simulation experiment (Tripathi, Kuriger, and Wan, 2009). In this paper, GA is used to create the SO. It should be noted that GA is one of the most popular metaheuristic methods that used in the SO. GA is perhaps the most mature metaheuristic method for SO in inventory management (Jalali and Nieuwenhuyse, 2015). GA is different from traditional optimization methods. It works with a coding of the parameter set. GA searches from a population of points. It uses the information of the fitness function and probabilistic transitions rules (Haq and Kannan, 2006). Therefore, integrating GA with simulation can cope with variability and complexity in supply chain. In SO, the major advantage of using simulation is that it does not require managers to have mathematical skills to apply it (Abuizam, 2011). Furthermore, simulation can be used to compare alternative inventory systems and to determine the effect of alternative inventory control policies on system performance. In this paper, the simulation model is created using Simio (Version: 7.121.12363) whose model looks like the real system. Details about Simio can be found in Pegden (2007). Simulation model is run for one year.

We created two SO models to solve inventory control problem in supply chain. In Model 1, total supply chain cost including average holding cost, order cost per use, backorder cost, order processing cost, and processing cost is minimized. In Model 2, the difference between underordering cost (backorder cost) and overordering cost (average holding cost) is minimized. The values of replenishment lead time and cost are given in 
Table 1 where values of parameters are determined by trial and error method. The replenishment lead time is assumed to be stochastic for DCs and suppliers. The DC's replenishment lead time includes order processing time at Suppliers, transportation time from Supplier to DCs, and processing time at DCs. The Suppliers' replenishment lead time includes processing time and order processing time.

Table 1. The parameter values related with cost and replenishment lead time and cost

\begin{tabular}{|c|c|}
\hline Suppliers & $\overline{\text { DCs }}$ \\
\hline Average Holding Cost: Uniform $(2,5)$ & Average Holding Cost: Uniform $(2,5)$ \\
\hline Unit Backorder Cost: Uniform $(20,40)$ & Unit Backorder Cost: Uniform $(20,40)$ \\
\hline Processing Cost: Uniform $(50,75)$ & Processing Cost: Uniform $(5,10)$ \\
\hline Order Cost Per Use: Uniform $(50,100)$ & Order Cost Per Use: Uniform $(50,100)$ \\
\hline $\begin{array}{l}\text { Order Processing Cost Rate: Uniform } \\
(2,5)\end{array}$ & $\begin{array}{l}\text { Order Processing Cost Rate: Uniform } \\
(2,5)\end{array}$ \\
\hline Cost Per Use: Uniform $(100,150)$ & Cost Per Use: Uniform $(10,20)$ \\
\hline $\begin{array}{l}\text { Processing Time: Triangular }(3,5,7) \\
\text { minutes }\end{array}$ & $\begin{array}{l}\text { Processing Time: Triangular }(1,2,3) \\
\text { minutes }\end{array}$ \\
\hline $\begin{array}{l}\text { Order Processing Time: Uniform }(2,5) \\
\text { hours }\end{array}$ & $\begin{array}{l}\text { Order Processing Time: Uniform }(2,5) \\
\text { hours }\end{array}$ \\
\hline Fons & $\begin{array}{l}\text { Transportation Time: Uniform }(1.25,3) \\
\text { days }\end{array}$ \\
\hline
\end{tabular}

\section{Results and Discussion}

In this study, two GA based SO are proposed to solve the inventory problems in supply chain. Model 1 minimizes the total supply chain cost over periods. The total cost of each DC and each Supplier are summed up to calculate the total supply chain cost over periods. Model 2 minimizes the total differences between overordering cost and underordering cost. The difference between the overordering cost and the underordering cost of each DC and each Supplier are summed up to calculate the total difference cost function over periods.

The results of optimization method (GA) are given in Table 2. For DCs, the average service level varies between $90.92 \%$ and $94.29 \%$. For Suppliers, the average service level is at least $99 \%$. For the utilized average service level formula, one can refer to Göçken, Dosdoğru, Boru, and Geyik (2017). For supply chain members, minimum initial inventory level is 836 units while maximum initial inventory level is 1821 units. The reorder point varies between 152 units and 197 units. The order-up-to level varies between 580 units and 881 units.

In this study, total supply chain cost includes five different cost components as given in Table 3 and 4. The analysis results showed that the largest share for DC1 with Model 1 is order processing cost whose value is $32 \%$ while the largest share for DC1 with Model 2 is backorder cost whose value is $40 \%$. The largest share for DC2 with Model 1 and Model 2 is order processing cost whose value is $32 \%$. The largest share for DC3 with Model 1 is backorder cost and order processing cost whose values are $31 \%$. For DC3 with Model 2, order processing cost has the largest share and its value is $32 \%$. The smallest share for DCs with Model 1 and Model 2 is the processing cost. 


\section{Ç.Ü. Sosyal Bilimler Enstitüsü Dergisi, Cilt 29, Sayı 1, 2020, Sayfa 200-212}

The analysis of cost components for Suppliers is given in Table 4. The most critical cost component is processing cost for all Suppliers. The share of the processing cost varies between $72 \%$ and $78 \%$ for Suppliers. The share of the average holding cost in Suppliers varies between $16 \%$ and 23\%. The share of other cost components varies between $1 \%$ and $6 \%$ for Suppliers. The total supply chain cost in Model 1 is better than that of Model 2 and the cost difference is 4091.

Table 2. Average service levels and inventory control parameters for supply chain members

\begin{tabular}{|c|c|c|c|c|c|}
\hline $\begin{array}{c}\text { Supply Chain } \\
\text { Member }\end{array}$ & $\begin{array}{c}\text { Model } \\
\text { Type }\end{array}$ & $\begin{array}{c}\text { Initial } \\
\text { Inventory }\end{array}$ & $\begin{array}{c}\text { Reorder Point } \\
\text { (s) }\end{array}$ & $\begin{array}{c}\text { Order-up-to } \\
\text { Level (S) }\end{array}$ & $\begin{array}{c}\text { Average } \\
\text { Service } \\
\text { Level }\end{array}$ \\
\hline \multirow{2}{*}{ DC1 } & Model 1 & 836 & 197 & 880 & 0.936773 \\
\cline { 2 - 6 } & Model 2 & 1821 & 183 & 611 & 0.909194 \\
\hline \multirow{2}{*}{ DC2 } & Model 1 & 1447 & 197 & 880 & 0.939791 \\
\cline { 2 - 6 } & Model 2 & 1821 & 194 & 881 & 0.942884 \\
\hline \multirow{2}{*}{ DC3 } & Model 1 & 1484 & 197 & 880 & 0.933201 \\
\cline { 2 - 6 } & Model 2 & 1821 & 196 & 881 & 0.941401 \\
\hline \multirow{2}{*}{ Supplier1 } & Model 1 & 1484 & 192 & 858 & 0.996886 \\
\cline { 2 - 6 } & Model 2 & - & - & - & - \\
\hline \multirow{2}{*}{ Supplier2 } & Model 1 & 836 & 192 & 892 & 0.995533 \\
\cline { 2 - 6 } & Model 2 & 1523 & 194 & 792 & 0.997895 \\
\hline \multirow{2}{*}{ Supplier3 } & Model 1 & 1484 & 197 & 838 & 0.990043 \\
\cline { 2 - 6 } & Model 2 & 1523 & 152 & - & - \\
\hline \multirow{2}{*}{ Supplier4 } & Model 1 & - & - & 580 & 0.995850 \\
\cline { 2 - 6 } & Model 2 & 1523 & - & - & - \\
\hline \multirow{2}{*}{ Supplier5 } & Model 1 & - & - & & - \\
\cline { 2 - 6 } & Model 2 & - & & & \\
\hline
\end{tabular}

Table 3: The cost analysis of the DCs

\begin{tabular}{|c|c|c|c|c|}
\hline Cost components & Model Type & DC1 & DC2 & DC3 \\
\hline \multirow{2}{*}{ Average Holding Cost } & Model 1 & 13647 & 14922 & 14604 \\
\cline { 2 - 5 } & Model 2 & 11590 & 16337 & 16203 \\
\hline \multirow{2}{*}{ Order Cost Per Use } & Model 1 & 29641 & 29514 & 29718 \\
\cline { 2 - 5 } & Model 2 & 31073 & 29499 & 29407 \\
\hline \multirow{2}{*}{ Backorder Cost } & Model 1 & 38009 & 36218 & 40404 \\
\cline { 2 - 5 } & Model 2 & 58224 & 34808 & 34948 \\
\hline \multirow{2}{*}{ Order Processing Cost } & Model 1 & 40031 & 40002 & 39977 \\
\cline { 2 - 5 } & Model 2 & 41787 & 39807 & 39834 \\
\hline \multirow{2}{*}{ Processing Cost } & Model 1 & 4686 & 4595 & 4552 \\
\cline { 2 - 5 } & Model 2 & 4640 & 4494 & 4473 \\
\hline
\end{tabular}


Ç.Ü. Sosyal Bilimler Enstitüsü Dergisi, Cilt 29, Sayı 1, 2020, Sayfa 200-212

Table 4: The cost analysis of the Suppliers

\begin{tabular}{|c|c|c|c|c|c|}
\hline Cost components & Model Type & Supplier 1 & Supplier 2 & Supplier 3 & Supplier 4 \\
\hline \multirow{2}{*}{ Average Holding Cost } & Model 1 & 22260 & 18779 & 21535 & - \\
\cline { 2 - 6 } & Model 2 & - & 26284 & 24328 & 16636 \\
\hline \multirow{2}{*}{ Order Cost Per Use } & Model 1 & 1821 & 1860 & 1909 & - \\
\cline { 2 - 6 } & Model 2 & - & 1686 & 1757 & 2544 \\
\hline \multirow{2}{*}{ Backorder Cost } & Model 1 & 1827 & 3155 & 6797 & - \\
\cline { 2 - 6 } & Model 2 & - & 1148 & 2289 & 1163 \\
\hline \multirow{2}{*}{ Order Processing Cost } & Model 1 & 2431 & 2506 & 2570 & - \\
\cline { 2 - 6 } & Model 2 & - & 2292 & 2360 & 3450 \\
\hline \multirow{2}{*}{ Processing Cost } & Model 1 & 89603 & 89063 & 84779 & - \\
\cline { 2 - 6 } & Model 2 & - & 84981 & 85144 & 82324 \\
\hline
\end{tabular}

In order to evaluate proposed system in a more detailed way, we analyzed partially backordered order quantity (PBOQ), totally backordered order quantity (TBOQ), totally met order quantity (TMOQ), and P1 as given in Figure 2-4 for DCs. In $\mathrm{P} 1$, current inventory level of supply chain member is divided into incoming customer order quantity between two consecutive periods.

The analysis of DC1 is given in Figure 2. For DC1, approximately all of the PBOQ in Model 1 occur during lead time. Except lead time, at DC1 only one order is partially backordered with Model 1 and its PBOQ value is 7 units. All of the TBOQ occur during lead time with Model 1 at DC1. Utilizing Model 1 at DC1 13.59\% of the total TMOQ occurs during lead time. At DC1, all of the PBOQ and TBOQ occur during lead time with Model 2. At DC1, 16.47\% of the total TMOQ occurs during lead time with Model 2.
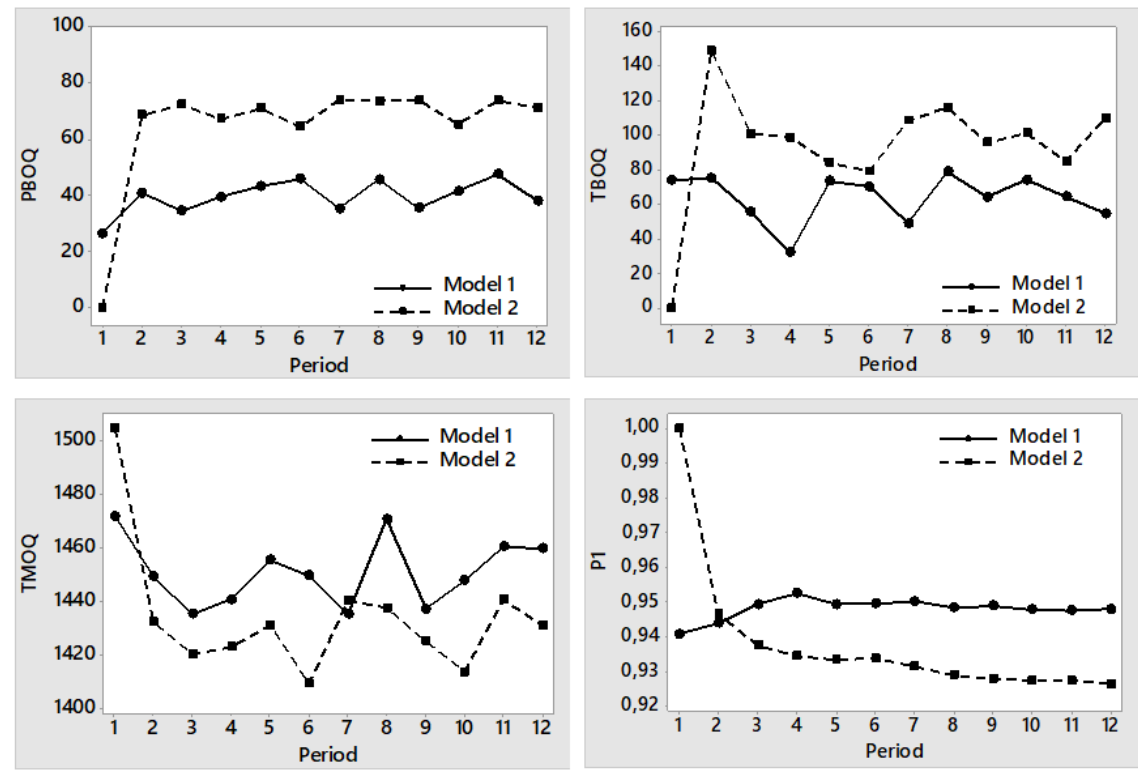

Figure 2. The analysis of DC1 
The analysis of DC2 is given in Figure 3. At DC2, approximately all of the PBOQ with Model 1 occur during lead time. Except lead time, at DC2 only one order is partially backordered with Model 1 and its PBOQ value is 16 units. All of the TBOQ occur during lead time with Model 1 at DC2. Utilizing Model 1 at DC2 13.63\% of the total TMOQ occurs during lead time. At DC2, all of the PBOQ and TBOQ occur during lead time with Model 2. At DC2, $12.9 \%$ of the total TMOQ occurs during lead time with Model 2.

The analysis of DC3 is given in Figure 4. At DC3, approximately all of the PBOQ occur during lead time with Model 1. Except lead time, only one order is partially backordered with Model 1 and its PBOQ value is 12 units at DC3. All of the TBOQ occur during lead time with Model 1 at DC3. Utilizing Model 1, 12.77\% of the total TMOQ occurs during lead time at DC3. At DC3, all of the PBOQ and TBOQ occur during lead time with Model 2. At DC3, 13.23\% of the total TMOQ occurs during lead time with Model 2.
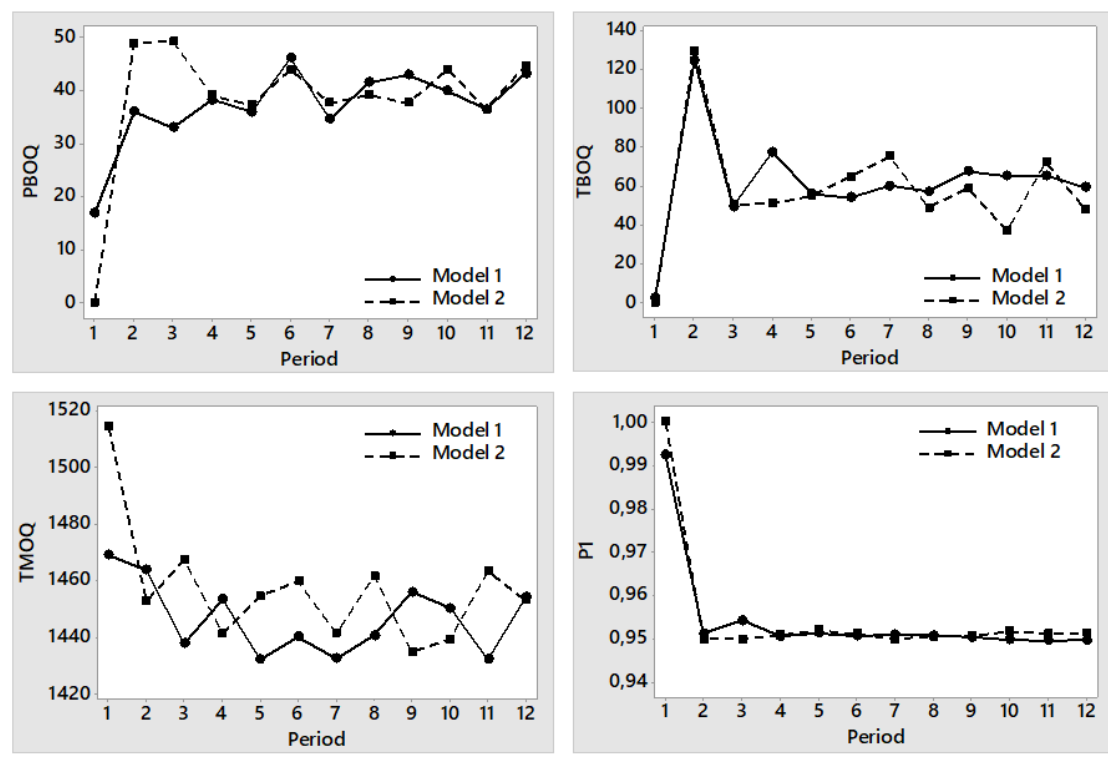

Figure 3. The analysis of DC2 

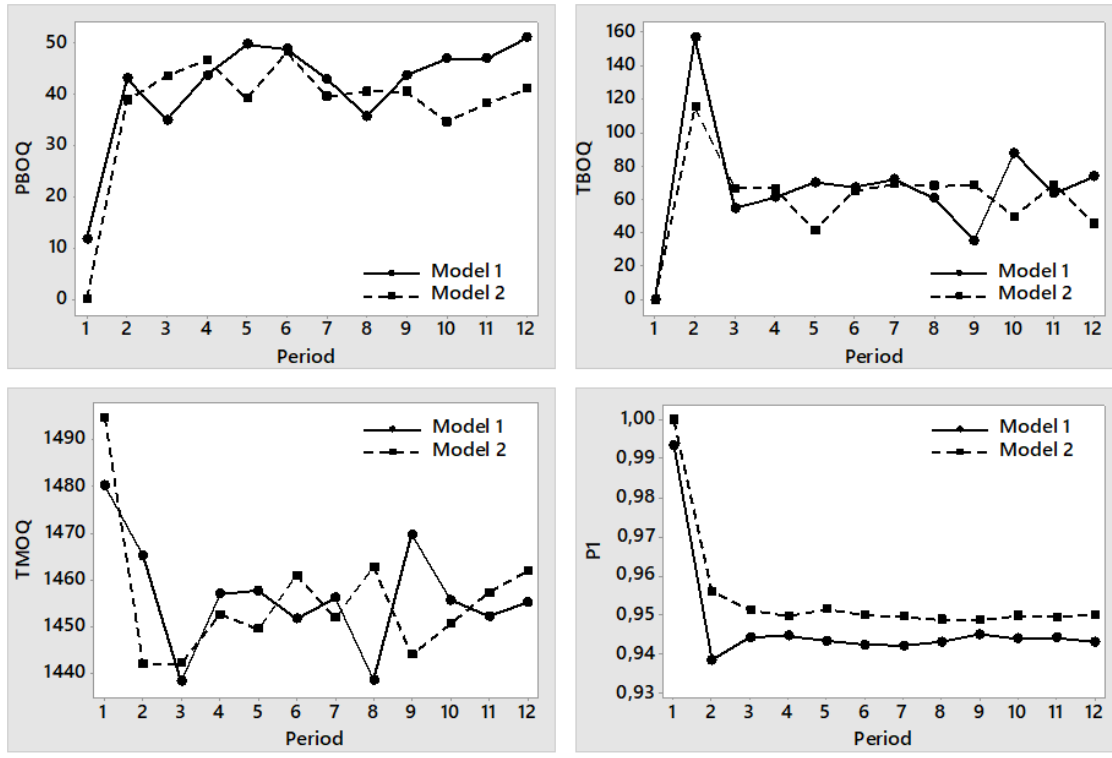

Figure 4. The analysis of DC3

The value of P1 at Supplier 1 is at least $99.04 \%$ with Model 1. The total PBOQ value is 60 units with Model 1 at Supplier 1. The value of P1 at Supplier 2 is at least 99.43\% with Model 1. The total PBOQ value is 100 units with Model 1 at Supplier 2. The value of P1 at Supplier 3 is at least $98.45 \%$ with Model 1. The total PBOQ value is 225 units with Model 1 at Supplier 3.

The value of P1 at Supplier 2 is at least $99.32 \%$ with Model 2. The total PBOQ value is 38 units with Model 2 at Supplier 2. The value of P1 at Supplier 3 is at least 98.92\% with Model 2. The total PBOQ value is 76 units with Model 2 at Supplier 3. The value of P1 at Supplier 4 is at least $99.43 \%$ with Model 2. The total PBOQ value is 37 units with Model 2 at Supplier 4. Note that the value of TBOQ is zero for all Suppliers with both Model 1 and Model 2.

\section{Conclusion}

Managing uncertain inventories is one of the most significant topics in supply chain. At this point SO can be sucessfully used since it is able to provide 'high-quality' solutions to inventory control system of supply chain members. Furthermore, SO can be easily adapted to different systems, while the basic logic of method stays unchanged. Also, SO is relatively flexible method.

This paper provides two SO models to respond changes and uncertainties in the supply chain, effectively. Model 1 minimizes the total supply chain cost over periods while Model 2 minimizes the differences between overordering cost and underordering cost. The results of the study showed that total supply chain cost at DCs with Model 1 is better than Model 2. The values of total PBOQ and TBOQ with Model 2 are higher than Model 1 at DCs. In addition, the value of total TMOQ with Model 2 is lower than 
Model 1 at DCs. Under this condition, Model 1 can be preferred to improve the supply chain performance.

\section{Acknowledgment}

This work was supported by Scientific Research Projects Commission of Adana Alparslan Türkeş Science and Technology University.

Project Number: 18103020.

\section{References}

Abuizam, R. (2011). Optimization of (s, S) periodic review inventory model with uncertain demand and lead time using simulation. International Journal of Management and Information System, 15(1), 67-80.

Bensoussan, A., Çakanyıldırım, M., Minjarez-Sosa, J. A., Sethi, S. P., \& Shi, R. (2010). An incomplete information inventory model with presence of inventories or backorders as only observations. Journal of Optimization Theory and Applications, 146(3), 544-580.

Cárdenas-Barrón, L. E. (2011). The derivation of EOQ/EPQ inventory models with two backorders costs using analytic geometry and algebra. Applied Mathematical Modelling, 35(5), 2394-2407.

Chen, J., Huang, S., Hassin, R., \& Zhang, N. (2015). Two backorder compensation mechanisms in inventory systems with impatient customers. Production and Operations Management, 24(10), 1640-1656.

Chung, K-J., \& Cárdenas-Barrón, L. E. (2012). The complete solution procedure for the EOQ and EPQ inventory models with linear and fixed backorder costs. Mathematical and Computer Modelling, 55(11-12), 2151-2156.

Göçken, M., Dosdoğru, A. T., Boru, A., \& Geyik, F. (2017). Characterizing continuous $(\mathrm{s}, \mathrm{S})$ policy with supplier selection using Simulation Optimization.Simulation, 93(5), 379-396.

Gurgur, C. Z., \& Altiok, T. (2008). Decentralized multi-product multi-stage systems with backorders. IIE Transactions, 40(3), 238-251.

Haq, A. N., \& Kannan, G. (2006). Design of an integrated supplier selection and multiechelon distribution inventory model in a built-to-order supply chainenvironment. International Journal of Production Research, 44(10), 19631985.

Jaggi, C. K., \& Arneja, N. (2011). Application of Chebyshev inequality in stochastic inventory model with controllable lead time and backorder discount. International Journal of Inventory Control \& Management, 1(1), 13-28.

Jalali, H., \& Nieuwenhuyse, I. V. (2015). Simulation optimization in inventory replenishment: a classification. IIE Transactions, 47(11), 1217-1235. 
Jawahar, N., Gunasekaran, A., \& Balaji, N. (2012). A simulated annealing algorithm to the multi-period fixed charge distribution problem associated with backorder and inventory. International Journal of Production Research, 50(9), 2533-2554.

Johansson, L., \& Olsson, F. (2017). Quantifying sustainable control of inventory systems with non-linear backorder costs. Annals of Operations Research, 259 (12), 217-239.

Johansson, L., \& Olsson, F. (2018). Age-based inventory control in a multi-echelon system with emergency replenishments. European Journal of Operational Research, 265(3), 951-961.

Kok, A. G. (1993). Backorder lead time behaviour in (s, Q)-inventory models with compound renewal demand. (Memorandum COSOR; Vol. 9333). Eindhoven: Technische Universiteit Eindhoven.

Mart, T., Duran, S., \& Bakal, İ. S. (2013). Tactical inventory and backorder decisions for systems with predictable production yield. International Journal of Production Economics, 143(2), 294-303.

Mercado, E. C. (2008). Hands-on inventory management. Taylor \& Francis Group, LLC.

Pegden, C. D. (2007). SIMIO: a new simulation system based on intelligent objects. In: Winter Simulation Conference, Washington, DC, 2293-2300.

Rabbani, M., Oliaei, M. T. B., Farrokhi-Asl, H., \& Mobini, M. (2017). A new mathematical model in cell formation problem with consideration of inventory and backorder: Genetic and particle swarm optimization algorithms. Iranian Journal of Management Studies, 10, 819-852.

Rad, M. A., Khoshalhan, F., \& Glock, C. H. (2014). Optimizing inventory and sales decisions in a two-stage supply chain with imperfect production and backorders. Computers \& Industrial Engineering, 74, 219-227.

Rogers, D. F., \& Tsubakitani, S. (1991). Newsboy-style results for multi-echelon inventory problems: backorders optimization with intermediate delays. Journal of the Operational Research Society, 42(1), 57-68.

Santis, R. B., de Aguiar, E. P., \& Goliatt, L. (2017). Predicting material backorders in inventory management using machine learning. In: IEEE Latin American Conference on Computational Intelligence (LA-CCI), Arequipa, 1-6.

Samouei, P., Kheirkhah, A. S., \& Fattahi, P. (2015). A network approach modeling of multi-echelon spare-part inventory system with backorders and quantity discount. Annals of Operations Research, 226, 551-563.

Sarker, B. R., Rochanaluk, R., \& Egbelu, P. J. (2014). Improving service rate for a treetype three-echelon supply chain system with backorders at retailer's level. Journal of the Operational Research Society, 65, 57-72.

Srivastav, A., \& Agrawal, S. (2016). Multi-objective optimization of hybrid backorder inventory model. Expert Systems with Applications, 51, 76-84.

Tripathi, M., Kuriger, G., \& Wan, H. (2009). An ant based simulation optimization for vehicle routing problem with stochastic demands. In: Proceedings of the 2009 Winter Simulation Conference (WSC), Austin, TX, USA, 2476-2487.

Yao, Y., Dong, Y., \& Dresner, M. (2010). Managing supply chain backorders under vendor managed inventory: An incentive approach and empirical analysis. European Journal of Operational Research, 203(2), 350-359. 
Ç.Ü. Sosyal Bilimler Enstitüsü Dergisi, Cilt 29, Sayı 1, 2020, Sayfa 200-212

Zhang, G. P., Patuwo, B. E., \& Chu, C-W. (2003). A hybrid inventory system with a time limit on backorders. IIE Transactions, 35(7), 679-687. 